\title{
PROJECT METHODS IN TECHNICAL EDUCATION AND THEIR INFLUENCE ON PUPILS RELATION TO SUBJECT
}

\author{
Jaroslav Zukerstein, Arnost Smolik \\ J. E. Purkyne University in Usti nad Labem, Czech Republic \\ jaroslav.zukerstein@ujep.cz, arnost.smolik@ujep.cz
}

\begin{abstract}
Motivation of the pupil and his relation to the subject can significantly affect his results. In technical education, it often happens for pupils that they are not sufficiently motivated to gain knowledge. The reasons may be different - with respect to the real conditions of elementary schools, it may be inappropriate school workshop, insufficient equipment, materials and didactic aids. Last but not the least, one of the reasons can be the competencies of the teachers in technical fields. These facts can ultimately result in insufficient motivation of teachers, which is then transferred to pupils, who are not sufficiently active during the teaching process. This can result in a negative relationship to the subject and low efficiency in gaining new knowledge, skills and knowhow. The paper deals with the experimental part of the research, which focuses on the issue of the relationship of pupils to the subject of practical work. It examines the connection between the inclusion of project methods during teaching and the popularity of technical subjects. In the paper we present basic research objectives, including hypothesis determination. The paper describes experimental research that was carried out at two primary schools. For the experiment the technique of two parallel groups was used, one experimental and the other control. The questionnaire was used as a research tool. There is a description, how the research has been carried out including a timetable and the main conclusions are presented here.
\end{abstract}

Keywords: project methods, subject, pupils, experimental research, teaching process.

\section{Introduction}

The research part of this paper is focused on the use of project methods in technical education within the subject of "practical work" at the second level of elementary school. This part of the research is primarily focused on the popularity of the teaching subject in pupils in relation to the inclusion of project methods [1]. The aim of the research part is to verify that the appropriate placement and use of project methods in the field of technical education influence the popularity and attitude of pupils to the subject. There are endless discussions about pros and cons of project methods [2]. In many cases it has been proven that preparations for project teaching are more demanding. Furthermore, many subjects are less suitable for application of project teaching methods, however, others can be very relevant. Generally speaking, natural sciences and technically-oriented subjects tend to be more suitable as they offer extend the motivational potential.

A hypothesis that expresses the expected dependence on technical education and the inclusion of project methods has been established. It is in line with the research goal and assumes a positive contribution to the use of project methods: The use of project methods in teaching in the subject of "practical work" increases the popularity of this subject in pupils and changes their attitude to this subject [3].

In a practical experiment within the subject "Practical Education" the correlation between popularity and implementation of both individual and group project methods has been researched [4]. The experiment has been thematically oriented at electrotechnics and renewable energy.

\section{Materials and methods}

The questionnaire method and the experimental method were used to verify the hypothesis. The questionnaire was directly related to the experiment. Determining the pupils' popularity and attitudes to the subject covered two different time periods, before and after the experiment. The questionnaire was compiled from closed questions, i.e. with alternative answers offered. Respondents were asked to indicate the appropriate answer by a cross in the box. The questionnaire consisted of nine items, which offered four alternative answers.

The questionnaire was designed to monitor the pupil's popularity and attitude not only to the subject of "practical work", but also to some other subjects (Mathematics, Czech language, History, and Physics). The inclusion of some other subjects had two reasons. Respondents did not feel that only the subject of "practical work" was monitored. It partially eliminated the possibility of distorted statements at least. The second reason was the issue of other unknown influences, which could lead to 
a change of the respondents' attitude and the popularity of all other subjects irrespective of the experimental effect. If there were significant changes in attitudes and popularity in all studied subjects, we could assume that this shift was caused by an unknown variable and we could not be certain that the change in relation to the subject of "practical work" was the result of experimental action.

In detecting certain properties, facts, attitudes, dependencies, etc. we were not be able to examine all elements of the base file, so it is necessary to select a representative sample from this file. The experiment was carried out at two primary schools in 2015, in six groups of pupils of about 15 (three classes, each divided into two groups - control and experimental.) In the control groups traditional teaching took place, in the experimental groups teaching with the inclusion of project methods according to the processed topic was tested. Because of the focus of the research and the determined hypothesis, the experiment was carried out with pupils of the 8th year of elementary schools, where there is sufficient space within the technical education to include even more demanding project methods.

Each experiment assumes an effort to make selection of groups of subjects, so that they are equivalent to experimental effects in certain features that affect the dependent variable. The ideal case would be random selection of a sufficient number of subjects into groups, when each subject has the same chance of getting into the control or experimental group. In practice, however, because of the possibilities of the experiment and the schools, it is not possible to regroup pupils beyond the class. So the task was to make a selection that would distort as little as possible the results of the experiment.

In the first part of the selection it was necessary to identify schools, in which the subject of "practical work" is taught, as the experiment concerned the verification of the hypothesis in relation to technical education. After finding out the real possibilities how to conduct the research, two elementary schools were selected, three classes of the eighth grade, where the "practical work" was taught and the thematic unit "Electrotechnics around us" was selected [5].

Due to the fact that the teaching of the subject of "practical work" requires dividing classes into two parallel groups, the research strategy was focused on the technique of parallel paired groups selected to some extent of controlled selection. The groups were selected within each class so that they were equivalent if possible. Before the start of the experiment, all pupils were given a test of initial knowledge and knowledge in the subject. Based on its results, two groups were created from each class so that the sum of the points achieved in the test was the same for each pairing group. Thus, a descending order of pupils was compiled according to the number of points achieved in the test for each class and the subsequent division into pairs (first and second in the order, third and fourth ...). From each pair one pupil was selected for control and one for the experimental group based on the result of a simple "throwing coin" method.

By the possibility of selecting groups by preserving the existing division of each class into two groups, one was chosen as experimental, the other was considered as the control group. In this case, it would certainly be very unlikely that the groups will be inequitable given the results achieved in the entry test. Such a division would bring some complications in determining the effects of experimental effects.

To verify the hypothesis, a questionnaire of pupil popularity and attitudes to the subject was prepared to monitor changes in these variables. For the questionnaire, the form of the requested response was selected as closed, with a certain number of pre-prepared answers, in this case the number of four. The answer best suited to each respondent should be marked with a cross in the appropriate box. The questionnaire items were focused on the following.

1. I am interested / not interested in this subject.

2. This subject is easy / difficult for me.

3. I understand / do not understand the new topic.

4. We get the information in the ready form always / almost not at all.

5. When teaching, we do interesting things almost always / almost never.

6. The way the teacher leads the lesson perfectly suits / does not suit me.

7. We solve problems on our own very often / never.

8. During the lesson I can get very enthusiastic about the new thing very often / never.

9. I find information outside the classroom very often / never. 
The form of closed answers was chosen to facilitate the evaluation of responses and to increase the respondents' willingness to fill in the questionnaire. For any of the questionnaire items it was not possible to choose only two mutually exclusive answers (dichotomous items). The number of four responses (polynomial items) was chosen. The compilation of the items has been done in order to create not too numerous, neither exhaustive offers, so that it is not necessary to mention in the offer the category "other answers" [6].

As mentioned above, some other subjects were included (Mathematics, Czech language, History, Physics) in the questionnaire, besides the subject of "practical work". One reason was to induce the feeling that not only the subject of "practical work" was observed. The main reason was to question of some unknown effects that could be tracked through other subjects. Changing the attitude of respondents and the popularity of all other subjects, irrespective of the experimental work carried out in the subject of "practical work", would be the influence of an unknown variable.

The questionnaire was designed according to the most important rules and requirements, which includes clear and comprehensible items, unambiguous formulation of items, caution in the formulation of items identifying causes, finding only the necessary data (questionnaire extent), etc. [6].

In the first phase we tested the input data in the area of the chosen topic "Electrotechnics around us", which was chosen in order to verify the established hypothesis. Based on the results of the initial testing, experimental and control groups were created. Due to the fact that for the subject of "practical work" each class is divided into two groups, regrouping these groups within one class did not interfere with the teaching process or the organization of teaching. Parallel paired groups were then selected to a certain extent by controlled selection, so that the sum of the points achieved in the test was approximately the same for all paired groups in one class. A total of 88 pupils participated in the experiment, the number of pupils in the experimental groups was 45, in control groups it was 43.

In the second phase the pedagogical experiment took place. Experimental changes were introduced in three experimental groups, i.e. independent variables. The lessons were based on a topic with a higher frequency of project methods. In the control groups, the teaching took place in the traditional way. To verify the hypothesis, different changes of the dependent variables (attitudes and popularity of the subject) in all groups were expected. The effect of other independent variables that are undesirable and interfere with the results of the experiment must be taken into account. The most important undesirable variable is probably the influence of the teacher in this case. If we chose another teacher for was considered experimental groups, his personality would play the greatest role, and this variable could significantly affect the research results. The Hawthorn effect [7] could have had the most negative effect in this case.

The third phase involved questioning of the pupils at the end of the experimental period. The questionnaire was filled in by all six groups, using the same questionnaire of attitudes and popularity of the subject as in the first phase of the research.

\section{Results and discussion}

The questionnaire was given to respondents simultaneously with the entrance test, after the distribution of the respondents into the experimental and control groups, the obtained data were analyzed according to the classification.

Table 1

I am interested / not interested in this subject:

\begin{tabular}{|c|c|c|c|c|}
\hline 1p & $\mathbf{1}$ & $\mathbf{2}$ & $\mathbf{3}$ & $\mathbf{4}$ \\
\hline Frequency. & 3 & 10 & 16 & 16 \\
\hline Rel. Freq. & $7 \%$ & $22 \%$ & $36 \%$ & $36 \%$ \\
\hline Average & S. error & Min & Median & Max \\
\hline $\mathbf{3 . 0 0}$ & 0.92 & 1 & 3 & 4 \\
\hline
\end{tabular}

After the experimental phase the questionnaire was submitted again and the obtained data were compared with the previous ones. The results were analyzed for each item of the questionnaire for the respondents of all three experimental groups as well as for the control groups. One questionnaire item 
is shown to track phenomena in the subject of practical activity (Table 1, item labelled 1p), the offered questionnaire responses are marked as phenomena 1 to 4 in descending order from 4 for the answer in the first place of the scale to 1 for the last answer of the scale. If we compare the results of the questionnaire that was assigned to the experimental and control groups before the experimental phase, we can observe significant shifts of the investigated areas in the experimental groups, i.e. the popularity of the subject and the attitude towards the subject.

Table 2

Results of the questionnaire before the experiment

\begin{tabular}{|c|c|c|c|c|c|c|c|c|c|c|c|}
\hline \multicolumn{10}{|c|}{ Values before the experiment } \\
\hline \multicolumn{10}{|c|}{ Experimental groups } & \multicolumn{7}{c|}{ Control groups } \\
\hline Item & Aver. & S. err. & Min & Med & Max & Item & Aver. & S. err. & Min & Med & Max \\
\hline $\mathbf{1}$ & 3.000 & 0.919 & 1 & 3 & 4 & $\mathbf{1}$ & 3.070 & 0.925 & 1 & 3 & 4 \\
\hline $\mathbf{2}$ & 3.578 & 0.494 & 3 & 4 & 4 & $\mathbf{2}$ & 3.744 & 0.436 & 3 & 4 & 4 \\
\hline $\mathbf{3}$ & 3.867 & 0.340 & 3 & 4 & 4 & $\mathbf{3}$ & 3.860 & 0.347 & 3 & 4 & 4 \\
\hline $\mathbf{4}$ & 3.222 & 0.940 & 1 & 4 & 4 & $\mathbf{4}$ & 3.209 & 0.978 & 1 & 4 & 4 \\
\hline $\mathbf{5}$ & 3.222 & 0.866 & 1 & 3 & 4 & $\mathbf{5}$ & 3.349 & 0.774 & 1 & 4 & 4 \\
\hline $\mathbf{6}$ & 3.444 & 0.685 & 2 & 4 & 4 & $\mathbf{6}$ & 3.465 & 0.659 & 2 & 4 & 4 \\
\hline $\mathbf{7}$ & 1.800 & 0.909 & 1 & 2 & 4 & $\mathbf{7}$ & 1.977 & 0.927 & 1 & 2 & 4 \\
\hline $\mathbf{8}$ & 3.044 & 0.842 & 1 & 3 & 4 & $\mathbf{8}$ & 3.093 & 0.802 & 1 & 3 & 4 \\
\hline $\mathbf{9}$ & 1.933 & 1.041 & 1 & 2 & 4 & $\mathbf{9}$ & 2.209 & 1.024 & 1 & 2 & 4 \\
\hline
\end{tabular}

In Tables 2 and 3 the observed variables are shown separately for the respondents of the experimental groups and for the respondents of the control groups in relation to the experiment before and after the experiment. Items in the questionnaire were analysed by use of elementary statistics. In the columns arithmetic mean, minimum, median and maximum have been presented.

Table 3

Results of the questionnaire after the experiment

\begin{tabular}{|c|c|c|c|c|c|c|c|c|c|c|c|}
\hline \multicolumn{10}{|c|}{ Ealues after the experiment } \\
\hline \multicolumn{10}{|c|}{ Experimental groups } & \multicolumn{7}{c|}{ Control groups } \\
\hline Item & Aver. & S. err. & Min & Med & Max & Item & Aver. & S. err. & Min & Med & Max \\
\hline $\mathbf{1}$ & 3.400 & 0.680 & 2 & 4 & 4 & $\mathbf{1}$ & 3.116 & 0.813 & 1 & 3 & 4 \\
\hline $\mathbf{2}$ & 3.622 & 0.485 & 3 & 4 & 4 & $\mathbf{2}$ & 3.698 & 0.459 & 3 & 4 & 4 \\
\hline $\mathbf{3}$ & 3.822 & 0.382 & 3 & 4 & 4 & $\mathbf{3}$ & 3.884 & 0.321 & 3 & 4 & 4 \\
\hline $\mathbf{4}$ & 2.756 & 0.898 & 1 & 3 & 4 & $\mathbf{4}$ & 3.233 & 0.936 & 1 & 4 & 4 \\
\hline $\mathbf{5}$ & 3.467 & 0.777 & 1 & 4 & 4 & $\mathbf{5}$ & 3.233 & 0.773 & 1 & 3 & 4 \\
\hline $\mathbf{6}$ & 3.489 & 0.654 & 2 & 4 & 4 & $\mathbf{6}$ & 3.488 & 0.624 & 2 & 4 & 4 \\
\hline $\mathbf{7}$ & 2.978 & 0.774 & 1 & 3 & 4 & $\mathbf{7}$ & 1.884 & 0.895 & 1 & 2 & 4 \\
\hline $\mathbf{8}$ & 3.311 & 0.694 & 1 & 3 & 4 & $\mathbf{8}$ & 2.977 & 0.821 & 1 & 3 & 4 \\
\hline $\mathbf{9}$ & 1.956 & 1.032 & 1 & 2 & 4 & $\mathbf{9}$ & 2.186 & 1.017 & 1 & 2 & 4 \\
\hline
\end{tabular}

Their values correspond with the answers as phenomena from 1 to 4 . A standard error has been subsequently determined. Compared to the control groups, where there were no significant shifts in the values, we can notice that in the experimental groups the items $1,5,7,8$ related to the popularity of the subject, interest in gaining knowledge and active involvement of pupils noticeably increased. On the contrary, the decrease of item 4 indicates the need to understand the structure of the curriculum. The scale is in the opposite order in this item, so the decrease is a positive phenomenon, pupils get less knowledge in the finished form and they have to show self-sufficiency and problem-solving activity.

It has been researched that knowledge acquisition is substantially enhanced by project methods. Students are during the teaching process forced to think about alternative approaches and thus discovering new skills. 


\section{Conclusions}

Subsequent analysis of data with statistical significance testing of the alpha difference of $5 \%$ with the rejection of the zero hypothesis in $30 \%$ of the items obtained from 88 respondents confirms the hypothesis as the results from the experimental groups due to the inclusion of the project methods in the teaching significantly shifted the popularity of the subject and attitudes to some of the categories of the teaching process that was expected. There were no statistically significant changes in the attitudes and popularity of the subject during the experiment in the control groups. Also, in relation to other subjects included in the questionnaire, changes due to unknown effects were not proven.

\section{References}

[1] Hutchinson T. Introduction to Project Work. Third edition. Oxford: Oxford University Press, 1991. $23 \mathrm{p}$.

[2] Knoll M. Project Method. In: Encyclopedia of Educational Theory and Philosophy, ed. C.D. Phillips. Vol. 2. Los Angeles, California: Sage 2014. pp. 665-669.

[3] Novotný J. Zvyšování zájmu žáků o technicky zaměřené předměty pomocí projektových metod (Increasing of pupil's interest of technical focused subject by the project methods). Proceedings of international conference "Trendy ve vzdělávání" ("Trends in Education"), June 15 - 16, 2006, Olomouc, Czech Republic, pp. 125-128. (In Czech).

[4] Silberman M. Active Learning: 101 Strategies to Teach Any Subject. First edition. Philadelphia: Temple University, 1996. 189 p.

[5] Zukerstein J. Pracoviště pro výrobu plošných spojů jako prostředek k uplatňování projektů ve výuce (Workplace for printed circuit board producing as a way for project methods application). Proceedings of international conference "Modernizace vysokoškolské výuky technických předmětů" ("Modernization of university education of technical subjects"), March 24 - 25, 1998, Hradec Králové, Czech Republic, pp. 318-320. (In Czech).

[6] Chráska M. Základy výzkumu v pedagogice (Basic research in Pedagogy). Olomouc: Palacký University, 2000. 257 p. (In Czech).

[7] Gavora P. Výzkumné metody v pedagogice (Research methods in Pedagogy). Brno: Paido, 1996. 130 p. (In Czech). 